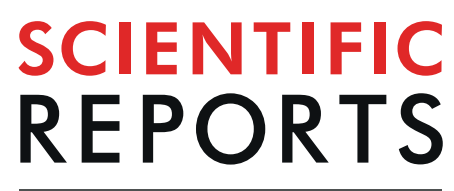

natureresearch

Published online: 28 January 2020

\title{
Publisher Correction: A Computational Method to Quantify the Effects of Slipped Strand Mispairing on Bacterial Tetranucleotide Repeats
}

\author{
Gregory P. Harhay, Dayna M. Harhay, James L. Bono, Sarah F. Capik, Keith D. DeDonder, \\ Michael D. Apley, Brian V. Lubbers, Bradley J. White, Robert L. Larson \& Timothy P. L. Smith \\ Correction to: Scientific Reports https://doi.org/10.1038/s41598-019-53866-z, published online 02 December \\ 2019
}

This Article contains a typographical error in the Introduction section.

"Where this postulate holds true, the fractional base compositions (FBC, the proportion of the number of A, C, $\mathrm{G}$, or T relative to the total number of bases in the SSR) for a base in SSM-mediated SSR length variants are necessarily nearly identical and essentially independent of the total length of the SSR, given the SSR > RU length."

should read:

"Where this postulate holds true, the fractional base compositions (FBC, the proportion of the number of A, C, G, or T relative to the total number of bases in the SSR) for a base in SSM-mediated SSR length variants are necessarily nearly identical and essentially independent of the total length of the SSR, given the SSR > > RU length."

(i) Open Access This article is licensed under a Creative Commons Attribution 4.0 International License, which permits use, sharing, adaptation, distribution and reproduction in any medium or format, as long as you give appropriate credit to the original author(s) and the source, provide a link to the Creative Commons license, and indicate if changes were made. The images or other third party material in this article are included in the article's Creative Commons license, unless indicated otherwise in a credit line to the material. If material is not included in the article's Creative Commons license and your intended use is not permitted by statutory regulation or exceeds the permitted use, you will need to obtain permission directly from the copyright holder. To view a copy of this license, visit http://creativecommons.org/licenses/by/4.0/.

(C) The Author(s) 2020 